\title{
Adult T-cell leukaemia/lymphoma in a patient with pulmonary tuberculosis and Norwegian scabies
}

\author{
Philippa Ashmore ${ }^{1}$, Moosa Patel ${ }^{* 1}$, Kim Roberg ${ }^{2}$, Jenifer Vaughan ${ }^{3}$, Tirelo Pitjadi ${ }^{4}$, Toyin Raheem Abdulraheem ${ }^{1}$, \\ Lucille Sarah Singh ${ }^{1}$, Muhammed Faadil Waja ${ }^{1}$, Vinitha Philip ${ }^{1}$, Atul Lakha ${ }^{1}$ \\ ${ }^{1}$ Division of Clinical Haematology, Department of Medicine, Chris Hani Baragwanath Academic Hospital and Faculty of Health \\ Sciences, University of the Witwatersrand, Johannesburg, South Africa \\ ${ }^{2}$ Division of Infectious Disease, Department of Medicine, Chris Hani Baragwanath Academic Hospital and Faculty of Health \\ Sciences, University of the Witwatersrand, Johannesburg, South Africa \\ ${ }^{3}$ Department of Molecular Medicine and Haematology, NHLS (National Health Laboratory Services), Faculty of Health Sciences, \\ University of the Witwatersrand, Johannesburg, South Africa \\ ${ }^{4}$ Department of Anatomical Pathology, NHLS (National Health Laboratory Services), Faculty of Health Sciences, University of \\ the Witwatersrand, Johannesburg, South Africa
}

Received: September 15, 2015

DOI: $10.5430 /$ crcp.v3n1p18
Accepted: November 15, $2015 \quad$ Online Published: November 21, 2015

URL: http://dx.doi.org/10.5430/crcp.v3n1p18

\begin{abstract}
Acute adult T-cell leukaemia (AATL) is a clinical subtype of adult T-cell leukaemia/lymphoma, a rare type of peripheral T cell lymphoma. It is associated with infection by the retrovirus Human T-Lymphotropic Virus Type-1 (HTLV-1), and is seen most commonly in HTLV-1 endemic areas. The tumour cells have polylobulated nuclei morphologically and are CD3+, CD4+ or CD8+, CD7-, express T-cell receptor $\alpha \beta$, and are CD25+. The disease has an aggressive clinical course associated with marked immunosuppression caused by HTLV-1, and a poor prognosis. We report a rare case of a young male patient who presented with AATL complicated by multiple opportunistic infections including pulmonary tuberculosis and Norwegian scabies. He also had chronic hepatitis B. This constellation of illnesses has not previously been reported from South Africa in a population where another retrovirus, Human Immunodeficiency Virus (HIV), is a far more common occurrence, as are the HIV-related lymphomas.
\end{abstract}

Key Words: Adult T-cell leukaemia/lymphoma, Human T-Lymphotropic Virus Type-1, Norwegian scabies, Aggressive course, South Africa

\section{INTRODUCTION}

Acute adult T-cell leukaemia (AATL) is one of four clinical subtypes of the rare and aggressive mature peripheral T-cell malignancy adult T-cell leukaemia/lymphoma. It is associated with the retrovirus Human T-Lymphotropic Virus Type-1 (HTLV-1). The other subtypes include: smouldering, lymphomatous, and chronic. ${ }^{[1]}$ It is most commonly seen in HTLV-1 endemic areas such as southern Japan, Central and South America, the Caribbean, Western and Central Africa, and part of the Middle East. ${ }^{[2]}$ Transmission occurs via mother-to-child (vertical transmission), unprotected sexual contact, and contact with infected blood. Less than 5\% of the 15-20 million people infected with the virus develop adult T-cell leukaemia/lymphoma, approximately $60 \%$ of

\footnotetext{
*Correspondence: Moosa Patel; Email: moosa.patel@wits.ac.za; Address: Division of Clinical Haematology, Department of Medicine, Chris Hani Baragwanath Academic Hospital and Faculty of Health Sciences, University of the Witwatersrand, Johannesburg, South Africa.
} 
whom have the acute form. ${ }^{[3]}$ The precise mechanism by which HTLV-1 causes AATL is not fully understood but it seems that the insertion of the virus into the mature T-cell genome may be the first step in a multi-step process leading to oncogenesis and proliferation of a mature T-cell clone. ${ }^{[4,5]}$

In South Africa there is a much higher rate of Human Immunodeficiency Virus (HIV) infection compared to HTLV-1 (1:12.8 ratio in Gauteng Province between 1993 and 1994), ${ }^{[6]}$ and consequently a high rate of HIV-defining and HIVassociated haematological malignancies (for example NonHodgkin lymphoma and Hodgkin lymphoma respectively), as well as HIV and tuberculosis, and HIV and hepatitis B coinfections. In this context, we report a rare case of a young HIV negative male patient who presented with AATL complicated by marked immunosuppression leading to multiple opportunistic infections including pulmonary tuberculosis, chronic hepatitis B and Norwegian scabies.
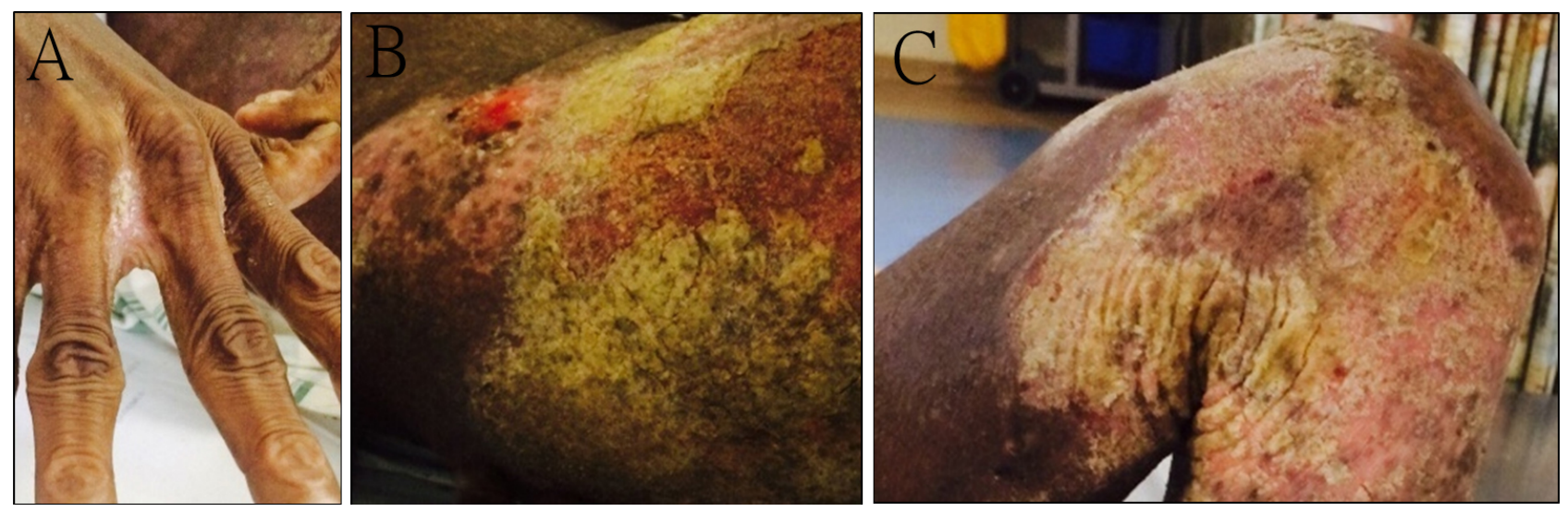

Figure 1. Pictures depicting the patient's rash with involvement in the web spaces of the hand (A), and clear plaque-like crusting of the trunk (B), and leg (C).
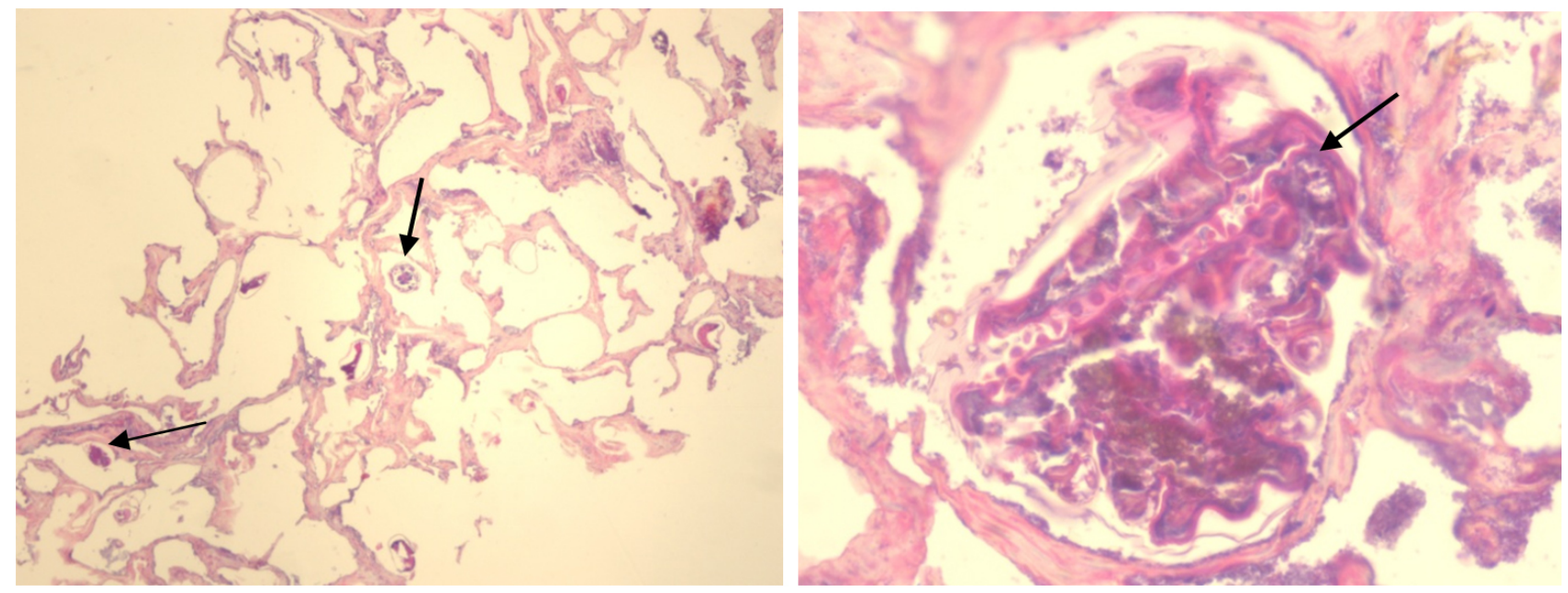

Figure 2. Skin biopsy. Left panel: Scabies mites burrowed in hyperkerototic material at $\times 10$ magnification (see arrows). Right panel: Scabies mite body at $\times 40$ magnification (see arrow).

Skin biopsy: Stained with Hematoxylin and Eosin.

\section{Clinical presentation}

The patient was a 29-year-old male who presented to our department complaining of fever, shortness of breath and general fatigue for a week. He also reported having a dry cough and loss of weight and appetite for the past few months. In addition, he described a pruritic skin rash that had been gradually worsening to cover most of his body over a period Published by Sciedu Press of five years. On examination, the most striking feature was that of an extensive crusting rash that covered the patient's body surface as depicted in Figure 1 (the skin biopsy findings are shown in Figure 2). He was febrile, generally wasted, had a poor performance status of 4 , and multiple contractures of both his upper and lower limbs. Further examination revealed bilateral cervical lymphadenopathy, and hepatomegaly of 
$6 \mathrm{~cm}$ below the right costal margin in the mid-clavicular line. (shown in Figure 3A and 3C), many of which had a There was no pallor, bleeding manifestations or palpable splenomegaly. On auscultation of the chest there were harsh breath sounds bilaterally with no signs of focal pathology.

On initial laboratory investigations the patient had a white cell count of $167.52 \times 10^{9} / \mathrm{L}$ with tumour cells of 155.79 $\times 10^{9} / \mathrm{L}$ on the differential count. He was mildly anaemic and thrombocytopaenic (haemoglobin $12.1 \times 10^{9} / \mathrm{L}$; platelet count $117 \times 10^{9} / \mathrm{L}$ ). The peripheral blood smear showed a morphologically heterogenous population of tumour cells

"flower"-like appearance. His serum lactate dehydrogenase was markedly raised at $1,146 \mathrm{U} / \mathrm{L}$, and his uric acid was $0.53 \mathrm{mmol} / \mathrm{L}$. His urea and electrolyte panel was normal apart from a pseudo-hyperkalaemia due to the high tumour burden $(7.5 \mathrm{mmol} / \mathrm{L})$ and a hypercalcaemia (corrected calcium $3.10 \mathrm{mmol} / \mathrm{L}$ ). His HTLV-1 IgG antibody test was positive, and he was HIV negative. The CD4 count was $23^{\circ} 202 \times$ $10^{6} / \mathrm{L}$, which is likely secondary to increased CD4+ tumour cells. He was also found to have chronic hepatitis B viral infection.

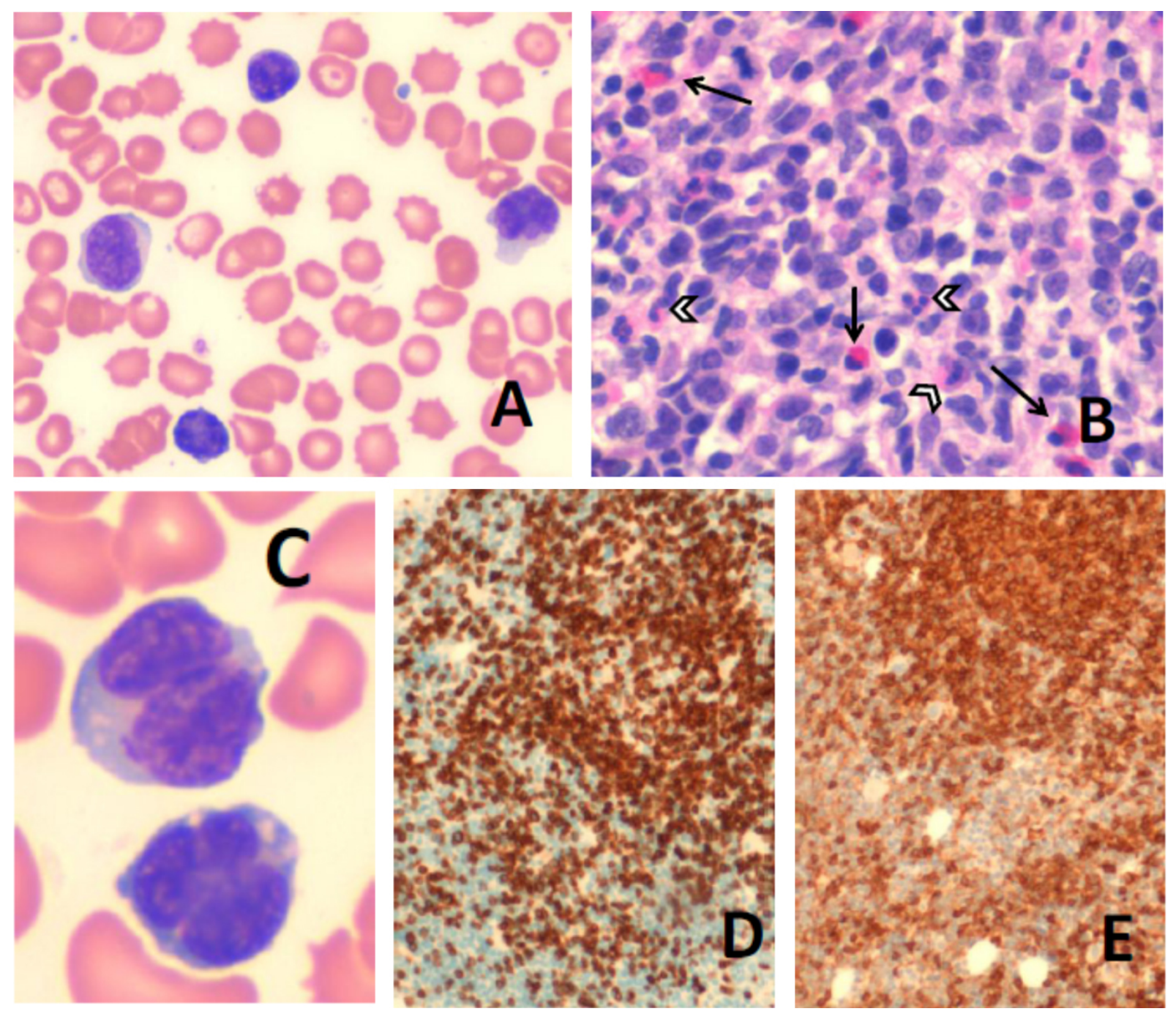

Figure 3. Images from the peripheral blood ( $\mathrm{A}$ and $\mathrm{C}$ ) and trephine biopsy (B, D and E). The tumour cells were morphologically heterogeneous, with some cells being smaller in size with high nuclear:cytoplasmic ratios, and others having a more bulky basophilic cytoplasm (A). Several had deep nuclear lobulation, imparting a "flower"/"clover leaf" appearance (shown at high power in C). B: A high power view of a focus of infiltration in the bone marrow trephine biopsy. The tumour cells are distributed in a sheet-like fashion, interspersed by occasional eosinophils (black arrows) and neutrophils (white arrow heads). D and E: Immunohistochemical staining for CD3 and CD4 of the trephine biopsy respectively.

Peripheral blood (A and C)- stained with May-Grünwald Giemsa, $500 \times$ and $1000 \times$ magnification respectively. Bone marrow trephine (B) stained with Hematoxylin and Eosin, $400 \times$ magnification. D and E: $100 \times$ magnification. 
On microbiological investigation the patient had a positive blood culture (FAN aerobic) for Staphylococcus aureus, which was sensitive to cloxacillin, as well as culturing extended spectrum beta lactamase Eschericia coli on urine that was sensitive to ertepenem and amikacin. On sputum analysis using the Gene Xpert $^{\complement}$ assay Mycobacterium tuberculosis complex was detected that was sensitive to rifampicin. A skin biopsy was performed which confirmed the diagnosis of Norwegian scabies (see Figure 2).

A bone marrow aspirate and trephine were performed and showed extensive infiltration by a malignant population of cells that expressed CD2, CD3, CD4, CD5, and CD25, with aberrant loss of CD7 (see Figures 3, 4). This confirmed a diagnosis of HTLV-1 associated AATL, complicated by multiple co-infections.

The patient was initially managed supportively with appropriate antibiotic treatment for his bacterial infections (including anti-tuberculous therapy, cloxacillin, ertapenem, and amikacin). He was also commenced on corticosteroids (prednisone), analgesia and intravenous fluid therapy. Additionally, he received a bisphosphonate (zolendronic acid) to treat his hypercalcaemia. Cytoreductive chemotherapy was administered with a COP regime (cyclophosphamide, vincristine, and prednisone). He was planned to receive antiviral therapy, but he sadly demised within two weeks of his first presentation, from septicaemia.
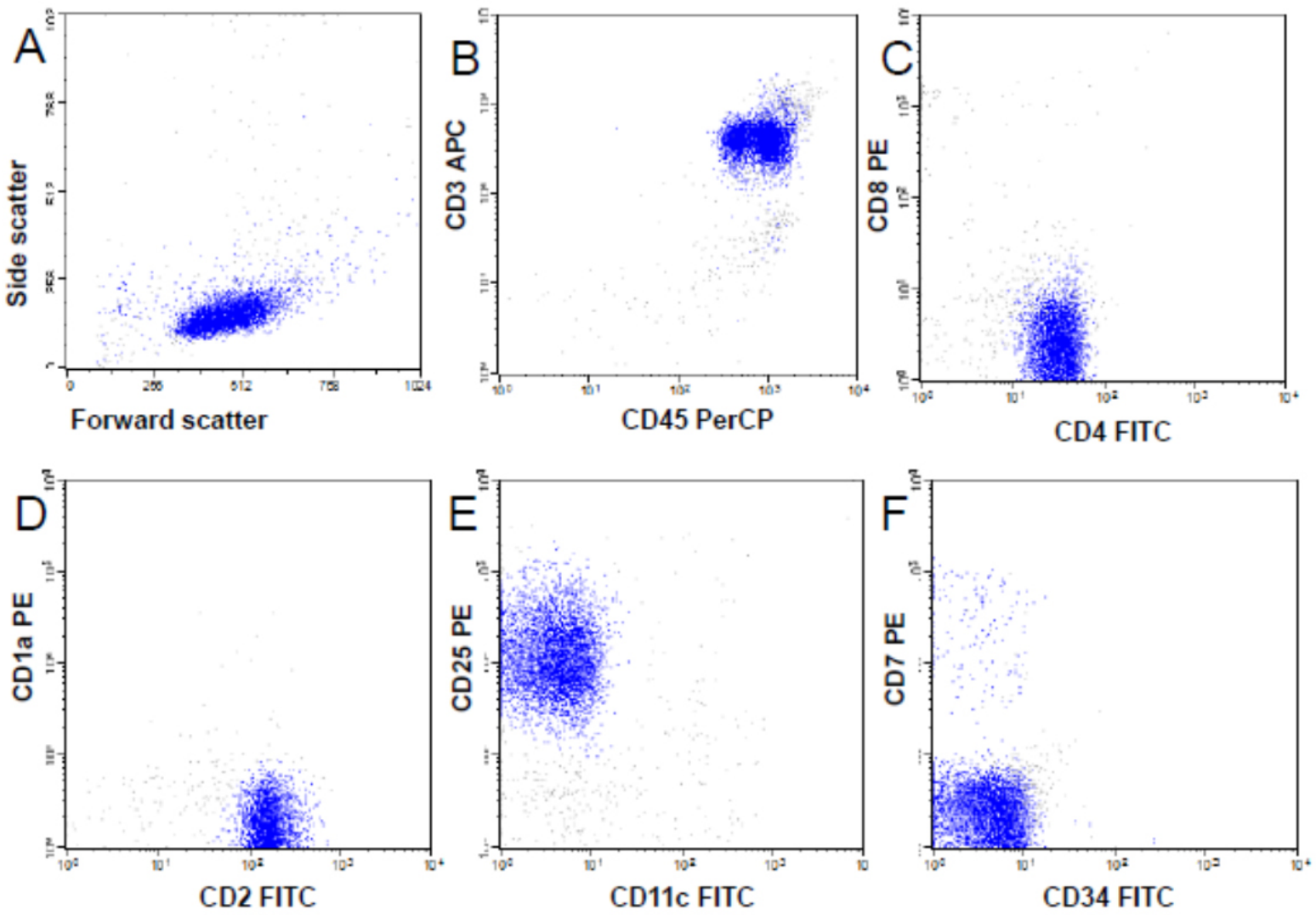

Figure 4. Flow cytometry findings. The lymphocytes were gated by forward light scatter vs side light scatter (A). The tumour cells (indicated in blue) were predominantly small in size, and expressed CD45 ++, CD3 ++/+++ (B), CD4 +/++ (C), $\mathrm{CD} 2++(\mathrm{D})$ and CD25 ++ (E) with aberrant loss of CD7 expression (F).

APC, Allophycocyanin; FITC, fluorescein isothiocyanate; PE, phycoerythrin; PerCP, Peridinin chlorophyll

\section{DisCuSSION AND CONCLUSION}

Acute adult T-cell leukaemia/lymphoma is a rare diagnosis outside of HTLV-1 endemic areas. At CHBAH, the most common adult leukaemia is acute myeloid leukaemia and the most common adult haematological malignancy is nonHodgkin lymphoma, often associated with HIV infection. There are no reports in the literature of HTLV-1 associated
AATL with Norwegian scabies, pulmonary tuberculosis, and chronic hepatitis B, all occurring in a single patient in South Africa.

The clinical presentation of our patient is typical of AATL - with regard to the immunocompromised state, "B" symptoms, lymphadenopathy, hepatomegaly, hypercalcaemia and 
the presence of CD2/3/4/25+ tumour cells with aberrant loss of CD7. His young age is unusual and likely related to vertical transmission of the HTLV-1, as the peak age of onset in HTLV-1 endemic areas is 50-69 years. ${ }^{[7]}$ Additionally, his coinfection with hepatitis B virus may well have been acquired by the same route of transmission. ${ }^{[8]}$ The opportunistic infections in this patient, namely pulmonary tuberculosis and Norwegian scabies, relate to the ineffective cellular immunity seen in patients with HTLV-1 and AATL. ${ }^{[9-11]}$

Poor prognostic factors for AATL are reported to be: involvement of the bone marrow, high serum lactate dehydrogenase (LDH) level, poor performance status, age 40 years or over, hypercalcaemia, thrombocytopaenia, eosinophilia, p53 mutation, and p16 deletion. ${ }^{[12]}$ Our patient had a number of these factors, and his poor performance status, emaciation and very poor general condition, together with multiple infections, directly contributed to his early demise. As such, we were unable to optimise his therapy for AATL by giving him combination chemotherapy together with, most importantly, antiviral agents in the form of zidovudine and interferon$\alpha .{ }^{[12,13]}$ The possible curative therapy of an allogeneic stem cell transplant was unfortunately not a consideration in his case.

Although HTLV-1 infection is not endemic in South Africa, clinicians need to be aware of the two major disease entities associated with HTLV-1, namely tropical spastic paraparesis and adult T-cell leukaemia/lymphoma. ${ }^{[7]}$ At CHBAH, fewer than ten patients have been seen with adult T-cell leukaemia/lymphoma in the last 30 years. This includes a report of the first patient with adult T-cell leukaemia/lymphoma that was published from CHBAH in 1995. ${ }^{[14]}$ However, the association of AATL with Norwegian scabies, tuberculosis, hepatitis B infection and multiple bacterial infections has not previously been encountered.

\section{ETHICS APPROVAL}

Ethics approval for this study was gained from the Human Research Ethics Committee (Medical) of the University of Witwatersrand, Johannesburg, South Africa.

\section{CONFLICTS OF INTEREST DISCLOSURE}

All the authors declare that there are no conflicts of interest.

\section{ACKNOWLEDGEMENTS}

We acknowledge and thank the staff of the Clinical Haematology Unit, Department of Medicine, CHBAH, as well as the Haematology and Molecular Medicine and Anatomical Pathology staff of the NHLS, CHBAH and Faculty of Health Sciences, University of the Witwatersrand, Johannesburg, South Africa.

\section{REFERENCES}

[1] Swerdlow S, Campo E, Harris N, editors. World Health Organization Classification of Tumours of Haematopoietic and Lymphoid Tissues. Lyon: IARC Press; 2008.

[2] Gessain A, Cassar O. Epidemiological Aspects and World Distribution of HTLV-1 Infection. Front Microbiol. 2012; 3: 388. PMid: 23162541. http://dx.doi.org/10.3389/fmicb. 2012.00388

[3] Marcais A, Suarez F, Sibon D, et al. Therapeutic options for adult T-cell leukemia/lymphoma. Curr Oncol Rep. 2013 Oct; 15(5): 457 64. PMid: 23943384. http://dx.doi.org/10.1007/s11912-0 13-0332-6

[4] Franchini G. Molecular mechanisms of human T-cell leukemia/lymphotropic virus type I infection. Blood. 1995 Nov 15; 86(10): 3619-39. PMid: 7579327.

[5] Matsuoka M, Jeang KT. Human T-cell leukaemia virus type 1 (HTLV1) infectivity and cellular transformation. Nat Rev Cancer. 2007 Apr; 7(4): 270-80. PMid: 17384582. http://dx.doi.org/10.1038/n rc2111

[6] Taylor MB, Parker SP, Crewe-Brown HH, et al. Seroepidemiology of HTLV-I in relation to that of HIV-1 in the Gauteng region, South Africa, using dried blood spots on filter papers. Epidemiol Infect. 1996 Oct; 117(2): 343-8. PMid: 8870632. http: //dx.doi.org/10.1017/S0950268800001527

[7] Tajima K, Tominaga S. Epidemiology of adult T-cell leukemia/lymphoma in Japan. Curr Top Microbiol Immunol. 1985; 115: 53-66. http://dx.doi.org/10.1007/978-3-642-7
[8] Moreira M, Ramos A, Netto E, et al. Characteristics of co-infections by HCV and HBV among Brazilian patients infected by HIV-1 and/or HTLV-1. Braz J Infect Dis. 2013; 17(6): 661-6. PMid: 24029434. http://dx.doi.org/10.1016/j.bjid.2013.04.009

[9] Heukelbach J, Feldmeier H. Scabies. Lancet. 2006 May 27; 367(9524): 1767-74. http://dx.doi.org/10.1016/S0140-673 6(06) 68772-2

[10] Marsh BJ. Infectious complications of human $\mathrm{T}$ cell leukemia/lymphoma virus type I infection. Clin Infect Dis. 1996 Jul; 23(1): 138-45. PMid: 8816143 http://dx.doi.org/10.1093/clinids/23.1.138

[11] Kaplan JE, Camara T, Hanne A, et al. Low prevalence of human T-lymphotropic virus type I among patients with tuberculosis in Senegal. J Acquir Immune Defic Syndr. 1994 Apr; 7(4): 418-20. PMid: 8133454

[12] Tsukasaki K, Hermine O, Bazarbachi A, et al. Definition, prognostic factors, treatment, and response criteria of adult T-cell leukemialymphoma: a proposal from an international consensus meeting. J Clin Oncol. 2009 Jan 20; 27(3): 453-9. PMid: 19064971. http: //dx.doi.org/10.1200/JC0.2008.18.2428

[13] Bazarbachi A, Suarez F, Fields P, et al. How I treat adult T-cell leukemia/lymphoma. Blood. 2011; 118(7): 1736-45. PMid: 21673346. http://dx.doi.org/10.1182/blood-201 1-03-345702

[14] Patel M, Stevens W, Crewe-Brown HH, et al. Adult T cell Leukaemia/Lymphoma. S Afr J Epidemiology and Infection. 1995; 10(1): 6-7.

ISSN 2331-2726 E-ISSN 2331-2734 